\title{
Facilitation of tree saplings by nurse plants: Microhabitat amelioration or protection against herbivores?
}

\author{
Gómez-Aparicio, Lorena ${ }^{1,2^{*}}$; Zamora, Regino ${ }^{1}$; Castro, Jorge ${ }^{1}$ \& Hódar, Jose A. ${ }^{1}$ \\ ${ }^{1}$ Grupo de Ecología Terrestre, Dpto. Ecología, Facultad de Ciencias, Universidad de Granada. Granada, ES-18071, \\ Spain. ${ }^{2}$ Present address: Instituto de Recursos Naturales y Agrobiología de Sevilla (IRNAS, CSIC) PO Rox 1052, \\ Sevilla, ES-41080, Spain; *Corresponding author; Fax+34 954624002; E-mail lorenag@irnase.csic.es
}

\begin{abstract}
Question: Positive interactions are predicted to be common in communities developing under high physical stress or high herbivory pressure due to neighbour amelioration of limiting physical and consumer stresses, respectively. However, when both stress sources meet in the same community, the relative importance of the two facilitation mechanisms is poorly understood. We ask: What is the relative importance of abiotic vs. biotic mechanisms of facilitation of tree saplings by shrubs in Mediterranean mountain forests?

Location: Sierra Nevada, SE Spain (1800-1850 m a.s.1.)

Methods: Saplings of four tree taxa (Acer opalus ssp. granatense, Quercus ilex, Pinus nigra ssp. salzmanii and P. sylvestris var. nevadensis) were planted following a $2 \times 2$ factorial design: two levels of herbivory (control and ungulate exclusion) and two microhabitats (under shrubs and in open areas). Sapling survival and growth were monitored for five years.

Results: Shrubs had positive effects on sapling survival both in control and ungulate excluded plots. This effect was speciesspecific, with shrubs increasing the survival of Acer opalus and Quercus ilex three and twofold, respectively, but having a minor effect on the Pinus species. Herbivory damage was also species-specific, being much higher for Acer opalus than for any other species. Shrubs did not protect saplings of any species against ungulates. Thus, all Acer saplings (the most damaged species) suffered herbivory outside the exclosures, which largely reduced sapling height.

Conclusions: Protection from abiotic stress (summer drought and winter frost) was much more relevant than protection from biotic stress (herbivory). However, we propose that the final balance between the two mechanisms can be expected to vary strongly between sites, depending on the relative magnitude of the different sources of stress and the intrinsic traits (e.g. palatability) of the species interacting.
\end{abstract}

Keywords: Abiotic stress; Facilitation mechanism; Herbivory pressure; Mediterranean mountain; Nurse shrub; Sapling survival; Species-specific effect.

Nomenclature: Castroviejo et al. (1986-2001) for tree species, and Molero-Mesa et al. (1992) for shrub species.

Abbreviations: PPFD = Photosynthetic photon flux density; RII = Relative interaction index $; \mathrm{VPD}=$ Vapour pressure deficit.

\section{Introduction}

The abundance, performance and spatial distribution of plant species are highly linked to the strength and sign of the interactions involving them in their communities (Roughgarden \& Diamond 1986; Brown et al. 2001). In 1994, Bertness \& Callaway proposed a conceptual model suggesting that strong positive interactions should be particularly common in communities developing under high abiotic stress and in communities with high consumer pressure, whereas competition should be the dominant interaction under mild physical conditions and low consumer pressure. Since then, a large number of empirical studies have supported this hypothesis by reporting that positive interactions are the rule under severe physical conditions (Mulder et al. 2001; Tewksbury \& Lloyd 2001; Callaway et al. 2002; Gómez-Aparicio et al. 2004). Consumer driven associational benefits also occur in systems with high consumer pressure (Rousset \& Lepart 1999; Meiners \& Martinkovic 2002; García \& Obeso 2003; Baraza et al. 2006). However, only a few studies have tried to disentangle the relative importance of the two mechanisms of facilitation for the same community (e.g. Callaway 1992).

Mediterranean mountain forests represent an ideal system to simultaneously test the importance of abiotic (microhabitat amelioration) and biotic (herbivory protection) mechanisms of facilitation in plant communities. On the one hand, these systems are characterized by a strong summer drought, which severely limits regeneration of tree and shrub species by causing high seedling and sapling mortality during the early stages of establishment (Rey \& Alcántara 2000; García 2001; Traveset et al. 2003; Castro et al. 2004a, 2005). Because of the relevance of drought as a stress factor, the amelioration of extreme summer climatic conditions by shrub canopies has been proposed as a key facilitation mechanism underlying the spatial association between tree propagules and shrubs in many Mediterranean systems (García 2001; Gómez et al. 2001; Castro et al. 2004b; Gómez-Aparicio et al. 2005a). Moreover, the Mediterranean high mountains can 
suffer extremely low temperatures in winter, and there is already some evidence suggesting that protection from winter frosts could also represent an important facilitation mechanism in these systems (Castro et al. 2002).

On the other hand, herbivory by ungulates has influenced vegetation patterns throughout the Mediterranean Basin for thousands of years (Callaway \& Pugnaire 1999; Zamora et al. 2000). Through a selective consumption of seedlings and saplings, herbivores can alter the course of ecological succession and consequently the species composition of a plant community (Pickett et al. 1987; Huntly 1991; Crawley 1997; Baraza et al. 2006). Thus, the high herbivore pressure characteristic of mediterranean forests has motivated the eradication of deciduous species in favour of the better defended evergreens (Cuartas \& García-Gónzalez 1992; Mesón \& Montoya 1993). In this scenario, successful tree establishment could be limited to refuges provided by shrub canopies, especially for palatable species. In fact, some studies have shown shrubs to protect saplings of woody species thanks to deterrents such as toxins or thorns, or simply by hiding them (Brown \& Ewel 1987; García \& Obeso 2003; Bakker et al. 2004). However, others have shown the opposite pattern (Hjältén \& Price 1997; Ibañez \& Schupp 2001; Rebollo et al. 2002).

In this work, we experimentally analyse the relative importance of microclimate modification vs. protection against herbivory as mechanisms of facilitation of tree saplings by nurse shrubs. To explore the species specificity of the mechanisms, we chose four of the main tree species inhabiting Mediterranean mountain forests: Acer opalus ssp. granatense, Quercus ilex, Pinus nigra ssp. salzmannii and $P$. sylvestris var. nevadensis. The response of tree saplings to the presence of shrubs, herbivores and their interaction was monitored over five years, which allowed us to examine the variation in time of the relative importance of the two facilitation mechanisms. To our knowledge, no other study is available on a long-term analysis of the relative importance of abiotic vs. biotic facilitation mechanisms on sapling performance of several tree species. The results from this study provide new insights into the mechanisms underlying the spatial patterns of regeneration associated with shrubs as reported for many woody species in stressful environments (Callaway 1992; Rey \& Alcántara 2000; García et al. 2000; Gómez et al. 2001).

\section{Material and Methods}

Study area

The experiment was conducted between 1997-2001 at the Sierra Nevada National Park (Granada, SE Spain), on the northwestern slope of Loma de los Panaderos (Trevenque area, $37^{\circ} 5^{\prime} \mathrm{N}-3^{\circ} 28^{\prime} \mathrm{W}$; $1800-1850 \mathrm{~m}$ a.s.l.). The bedrock is calcareous, with slopes ranging between $5^{\circ}$ and $15^{\circ}$. The climate is subhumid mediterranean $(871$ mm annual mean; 1990-2002). Rainfall is concentrated in spring and autumn, alternating with hot, dry summers (39 mm summer mean, sum of $\mathrm{mm}$ in June, July and August; $1990-2002)$ and cold winters $\left(-0.1^{\circ} \mathrm{C}\right.$ mean minimum temperature for December-February; 19902002). Snow is common during winter, persisting up to two months, and frost occurs from November to April. Weather differed among the study years: 1997 and 1998 had relatively wet summers, with summer rainfall above average for the site $(71 \mathrm{~mm}$ and $47 \mathrm{~mm}$, respectively), whereas the last three years $(1999,2000$ and 2001) had relatively dry summers with rainfall below average (21.8 mm, $2 \mathrm{~mm}$ and $10 \mathrm{~mm}$, respectively). In addition, winter was much colder in 1998 than in any other year, with the mean minimum temperature being below zero $\left(-1.7^{\circ} \mathrm{C}\right.$ in 1998 vs. $0.2-1.5^{\circ} \mathrm{C}$ for the other years). The study area was formerly a mixed forest of $P$. sylvestris var. nevadensis, $P$. nigra ssp. salzmanii, $Q$.ilex, A. opalus ssp. granatense and Sorbus aria. In 1983, a fire in the study area burned ca. 8 ha of the original pine forest. Since then, the area has been recolonized by different successional species of shrubs intermingled with $1-3 \mathrm{~m}$ diameter interspaces of bare ground. The most abundant shrubs in the study zone are Salvia lavandulifolia, an evergreen reaching a maximum height of $50 \mathrm{~cm}$, and several species of deciduous spiny shrubs 1 - $2 \mathrm{~m}$ high, mainly Prunus ramburii, Crataegus granatensis and Berberis vulgaris ssp. australis (see Castro et al. 2002 for details on habitat structure). The main ungulate in the study zone is the Spanish ibex Capra pyrenaica. Saplings used in the experiment were provided by the Consejería de Medio Ambiente (Junta de Andalucía).

\section{Experimental design}

The experiment was initiated in March 1997. We selected three blocks (each ca. 0.5 ha) separated by $>$ $200 \mathrm{~m}$ in the study site. Two plots ( $0.25 \mathrm{ha}$ ) were marked per block, one being fenced to exclude ungulates from the plants and the other left unfenced as a control. These resulted in three ungulate excluded plots and three control plots. In each of the six plots, we planted two year old saplings of A. opalus, $Q$. ilex, $P$. nigra and $P$. sylvestris in two microhabitats: under the canopy of the most 
abundant deciduous spiny shrubs (Prunus ramburii, Crataegus granatensis and Berberis vulgaris; hereafter 'shrub microhabitat') and in open interspaces without vegetation (hereafter 'open microhabitat'). We pooled three species of spiny shrubs into the shrub microhabitat due to the fact that none were abundant enough to conduct the experiment. However, the three species have similar effects on soil moisture, nutrient content and understorey light levels (authors' unpubl. data) and therefore the physical environment surrounding the saplings in their understorey can be assumed to be comparable. We planted 15 saplings per tree species per microhabitat per plot ( $n=720$ saplings), with planting points randomly assigned. Planting holes in open interspaces were dug $40 \mathrm{~cm}$ deep with a mechanical auger diameter $30 \mathrm{~cm}$. A smaller auger bit (12 cm diameter) was used for planting in the shrub microhabitat to minimize damage to the shrub roots. In June 1997, before the onset of the summer drought, we examined the planted saplings, excluding from the study those that had died (3.5\%), presumably due to transplanting shock. As a result, the final number of saplings per treatment combination differed from 15, causing the design to be unbalanced. Sapling height in June 1997 was $7.2 \pm 0.5 \mathrm{~cm}$ for A. opalus $(n=175), 8.4$ $\pm 0.6 \mathrm{~cm}$ for $Q$. ilex $(n=173), 5.0 \pm 0.3 \mathrm{~cm}$ for $P$. nigra $(n=175)$ and $5.2 \pm 0.3 \mathrm{~cm}$ for $P$. sylvestris $(n=172)$. Initial height did not differ among microhabitats for any species ( $p>0.05$, one-way ANOVAs).

\section{Abiotic characterization of the microhabitats}

Abiotic environmental conditions in each microhabitat were characterized by measuring above and belowground microclimate and soil water content. Microclimatic conditions were measured with $\mathrm{HOBO} \mathrm{H} 8$ data loggers (Onset Computer Corporation, Bourne, MA, S US) located at ten sampling stations per microhabitat distributed randomly within the three blocks of the experiment. They recorded air temperature, soil temperature at $5 \mathrm{~cm}$ depth and relative humidity every 2 min during three cloudless summer days. Relative humidity and air temperature values were used to calculate the vapuor pressure deficit (VPD) as an indicator of the atmospheric evapotranspiration demand. PPFD was recorded with Hali light sensors (EIC SL, Madrid, Spain) cross-calibrated with a LI-190SA quantum sensor (Li-Cor, Lincoln, Nebraska, USA) connected to the data loggers. The same day that HOBO H8 sensors were positioned in the field, volumetric soil water content was recorded using ThetaProbe sensors (Delta-T Devices Ltd., Cambridge, UK). Measurements were made next to the microclimatic sensors at $20 \mathrm{~cm}$ depth.

\section{Sapling measurements}

Saplings were censused twice a year between June 1997 and October 2001, once after summer (October) and once after winter (April), with the exception of the year 2000 when only the summer census was conducted. For each sapling, we recorded: (1) survival, together with the most likely cause of mortality (distinguishing between summer drought, winter frost and herbivore damage); (2) height, measured from the soil surface to the apical bud and (3) herbivory damage, estimated as the percentage of browsed shoots in relation to the total number of shoots. These data were used to calculate two complementary herbivory indices for each year of the study (Zamora et al. 2001): risk of herbivory (estimated as the percentage of saplings browsed) and damage intensity (estimated only for sapling suffering herbivory as the percentage of browsed shoots in relation to the total number of shoots). In addition, we calculated the frequency of herbivory for the entire study period, estimated as the number of years a sapling was damaged (from 0 to 5), therefore indicating the risk of saplings suffering repeated herbivory.

\section{Data analysis}

Abiotic variables were compared between microhabitats using one-way ANOVAs (Proc GLM, Anon. 2002) with microhabitat as a fixed factor. For air and soil temperature and VPD, the mean values per sample point were introduced as dependent variables, in order to avoid pseudoreplication. In the case of photosynthetic photon flux density (PPFD), we considered the mean daily PPFD as a dependent variable.

Survivorship curves were analysed by Cox's Proportional Hazard semiparametric models (Proc PHREG, Anon. 2002), using the maximum partial likelihood as estimation method (Allison 1995). Block, ungulate exclusion, microhabitat, and species were introduced as factors. Cumulative survival at the end of the experiment was analysed using Generalized Logit Models (Proc CATMOD, Anon. 2002). The relationship between the facilitative effect of shrubs and the climatic characteristic of the study year was explored using a relative interaction index (RII, sensu Armas et al. 2004). RII was calculated as the difference in survival with and without nurse shrubs relative to the sum of both survival percentages. This index ranges from -1 to 1 , with positive values indicating facilitation and negative values competition.

For each species, sapling height was analysed using a multivariate ANOVA (MANOVA, Proc GLM, Anon. 2002). Univariate analyses of repeated measures (rmANOVAs) were not used since models were not comprised of independent orthogonal components (Von Ende 2001). Ungulate exclusion and microhabitat were 
introduced as between-group factors, whereas year was introduced as a within-group factor. Block was not considered in the analyses due to the absence of live saplings at the end of the experiment in some combinations of the four factors.

Risk of herbivory was analysed for each year using Generalized Logit Models (Proc CATMOD, Anon. 2002) with block, microhabitat and species as factors. Damage intensity was analysed using three-way ANOVAs (Proc GLM), with microhabitat and species as fixed factors and block as a random factor. Contingency analyses were used to analyse the frequency of herbivory for the entire study period, introducing the number of years with damage (from 0 to 5) as a multinomial dependent variable and microhabitat and species as independent factors. When necessary, data were previously log or arc-transformed. Throughout the paper, we applied the sequential Bonferroni correction to reduce type-I error when multiple comparisons were made (Cabin \& Mitchell 2000). Results are expressed as mean \pm 1 SE.

\section{Results}

\section{Abiotic characterization of the microhabitats}

All the microclimatic variables differed significantly among microhabitats (Table 1). Mean daily air and soil temperature were reduced by almost $10^{\circ} \mathrm{C}$ under shrubs. VPD was reduced by half, whereas PPFD was decreased by $70 \%$. In contrast, volumetric soil water content did not differ between microhabitats, being in all cases very low $(<4 \%$, Table 1$)$.

\section{Survival}

Survival analyses showed significant differences in the temporal sequence of mortality between blocks, microhabitats and species, but not between control and ungulate-excluded plots (Table 2). Similarly, cumulative survival at the end of the study varied between blocks $\left(\mathrm{L}-\mathrm{R} \chi^{2}=52.80, \mathrm{df}=2, p<0.0001\right)$, microhabitats $(\mathrm{L}-\mathrm{R}$
Table 2. Results of Cox regression analyses to determine the effects of block, ungulate exclusion, microhabitat, and species on sapling survival. For each significant factor, ad hoc comparisons are shown. Levels of all variables were codified using dummy variables.

\begin{tabular}{llrc}
\hline Source of variation & df & $L-R \chi^{2}$ & $p$ \\
\hline Block (B) & 2 & 52.05 & $<\mathbf{0 . 0 0 0 1}$ \\
Ungulate exclusion (U) & 1 & 0.19 & 0.664 \\
Microhabitat (M) & 1 & 20.54 & $<\mathbf{0 . 0 0 0 1}$ \\
Species (S) & 3 & 67.29 & $<\mathbf{0 . 0 0 0 1}$ \\
$\mathrm{B} \times \mathrm{U}$ & 2 & 6.83 & $\mathbf{0 . 0 3 3}$ \\
$\mathrm{B} \times \mathrm{M}$ & 2 & 3.10 & 0.212 \\
$\mathrm{~B} \times \mathrm{S}$ & 6 & 19.80 & $\mathbf{0 . 0 0 3}$ \\
$\mathrm{U} \times \mathrm{M}$ & 1 & 0.53 & 0.467 \\
$\mathrm{U} \times \mathrm{S}$ & 3 & 0.65 & 0.885 \\
$\mathrm{M} \times \mathrm{S}$ & 3 & 13.79 & $\mathbf{0 . 0 0 3}$ \\
Model & 24 & 166.07 & $<\mathbf{0 . 0 0 0 1}$ \\
Acer opalus vs. Quercus ilex & 1 & 0.001 & 0.974 \\
Acer opalus vs. Pinus nigra & 1 & 11.18 & $\mathbf{0 . 0 0 1}$ \\
Acer opalus vs. Pinus sylvestris & 1 & 27.97 & $<\mathbf{0 . 0 0 0 1}$ \\
Quercus ilex vs. Pinus nigra & 1 & 10.84 & $\mathbf{0 . 0 0 1}$ \\
Quercus ilex vs. Pinus sylvestris & 1 & 26.66 & $\mathbf{< 0 . 0 0 0 1}$ \\
Pinus nigra vs. Pinus sylvestris & 1 & 3.04 & 0.081 \\
Block 1 vs. Block 2 & 1 & 12.01 & $<\mathbf{0 . 0 0 0 1}$ \\
Block 1 vs. Block 3 & 1 & 7.54 & $\mathbf{0 . 0 0 8}$ \\
Block 2 vs. Block 3 & 1 & 0.36 & 0.546 \\
\hline
\end{tabular}

$\left.\chi^{2}=26.59, \mathrm{df}=1, p<0.0001\right)$ and species $\left(\mathrm{L}-\mathrm{R} \chi^{2}=\right.$ 46.25 , $\mathrm{df}=3, p<0.0001$ ), but not between control and ungulate excluded plots $\left(\mathrm{L}-\mathrm{R} \chi^{2}=1.85, \mathrm{df}=1, p=0.173\right)$. Cumulative survival in block 1 (49\%) was higher than in blocks $2(23 \%)$ and $3(24 \%)$, but in all three blocks survival followed the same among-microhabitat pattern. Saplings of the four species showed higher survival in the shrub than in the open microhabitat (Fig. 1), although differences were significant only for A. opalus and $Q$. ilex (significant Microhabitat $\times$ Species interaction term, Table 2). Thus, cumulative survival in the shrub microhabitat was threefold higher than in the open microhabitat for A. opalus saplings and almost twofold for $Q$. ilex saplings, both in control and ungulate excluded plots (Fig. 1). The main cause of mortality was summer drought $(66.5 \%)$, followed by winter frost $(32.2 \%)$, whereas mortality caused by ungulates was estimated

Table 1. Abiotic conditions measured under nurse shrubs and in open interspaces. Data were recorded every 2 min. for three cloudless summer days. Values are mean $\pm \mathrm{SE}$.

\begin{tabular}{|c|c|c|c|c|}
\hline \multirow[b]{2}{*}{ Abiotic variable } & \multicolumn{2}{|c|}{ Microhabitat } & \multirow[b]{2}{*}{$F$} & \multirow[b]{2}{*}{$p$} \\
\hline & Shrub & Open & & \\
\hline Air temperature $\left({ }^{\circ} \mathrm{C}\right)$ & $27.5 \pm 0.4$ & $36.9 \pm 0.9$ & 18.08 & $<0.0001$ \\
\hline Soil temperature $\left({ }^{\circ} \mathrm{C}\right)$ & $23.3 \pm 0.3$ & $31.4 \pm 0.6$ & 110.63 & $<0.0001$ \\
\hline Vapor pressure deficit (KPa) & $2.7 \pm 0.7$ & $5.4 \pm 0.2$ & 22.76 & $<0.0001$ \\
\hline Daily PPFD* (mmoles/m²) & $16.1 \pm 2.7$ & $47.2 \pm 5.2$ & 103.16 & $<0.0001$ \\
\hline Soil water content $(\% \mathrm{~V})$ & $3.5 \pm 0.2$ & $2.8 \pm 1.2$ & 1.64 & 0.213 \\
\hline
\end{tabular}




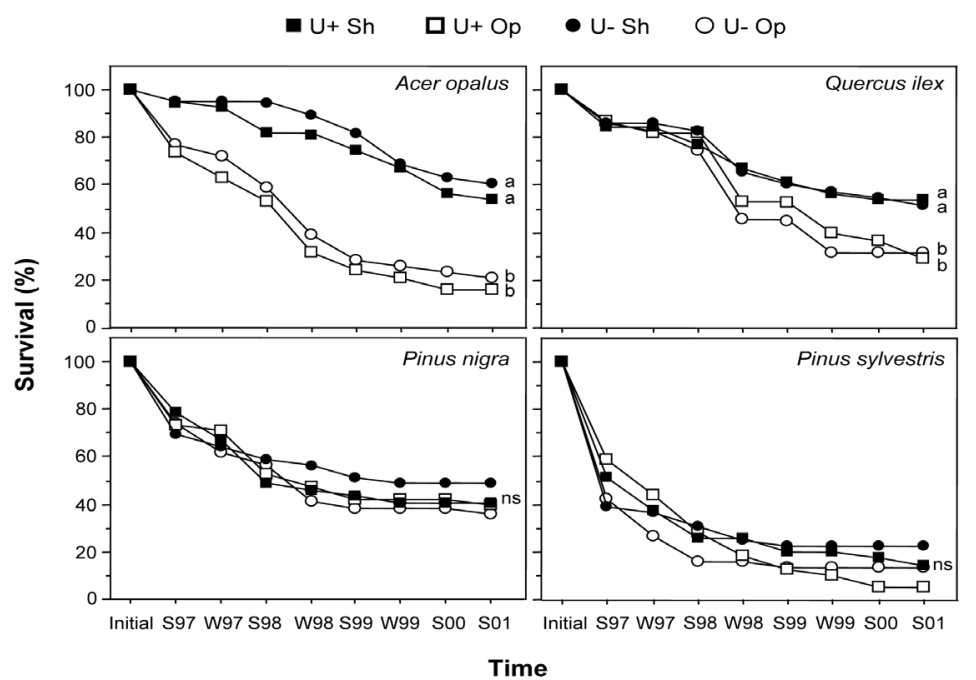

Fig. 1. Survival of experimental saplings throughout 5 years of study in the four experimental treatments. U+ = control plots; U= ungulate-excluded plots; $\mathrm{Sh}=$ shrub microhabitat; $\mathrm{Op}=$ open microhabitat $\mathrm{S}=$ summer; $\mathrm{W}=$ winter. Different letters indicate significant differences between experimental treatments (after Bonferroni correction) according to pairwise $\chi^{2}$ tests.

to be only $1.3 \%$. A. opalus and $Q$. ilex showed similar survivorship curves, but these differed from those of both Pinus species (Table 2). Thus, whereas P. nigra and $P$. sylvestris suffered a much higher mortality during the first summer than at any other time during the experiment, A. opalus and $Q$. ilex had more sustained mortality, with one peak the first summer and another the second winter (Fig. 1). The beneficial effect of shrubs varied among years and seasons. Despite the greatest overall mortality occurring in summer, the relative advantage of being beneath a shrub was greatest in the winter as shown by higher values of RII (Fig. 2). This was especially true in 1998, an exceptionally cold winter.

\section{Height growth}

Herbivory only affected height growth of A. opalus saplings (Table 3, Fig. 3). Thus, accumulated height growth after five years was more than twice as high for A. opalus saplings inside $(18.2 \pm 2.6 \mathrm{~cm})$ than outside the exclosures $(8.5 \pm 1.5 \mathrm{~cm})(F=7.88, \mathrm{df}=1, p=0.015$, one-way ANOVA). The microhabitat did not directly affect height growth of any of the four tree species (Table 3 ), but it interacted with ungulate exclusion in the case of A. opalus (Table 3 ). Thus, whereas there was no betweenmicrohabitat difference in growth of A. opalus saplings in the ungulate-excluded plots, saplings in the control plots grew higher under shrubs than in open interspaces (Fig. 3).

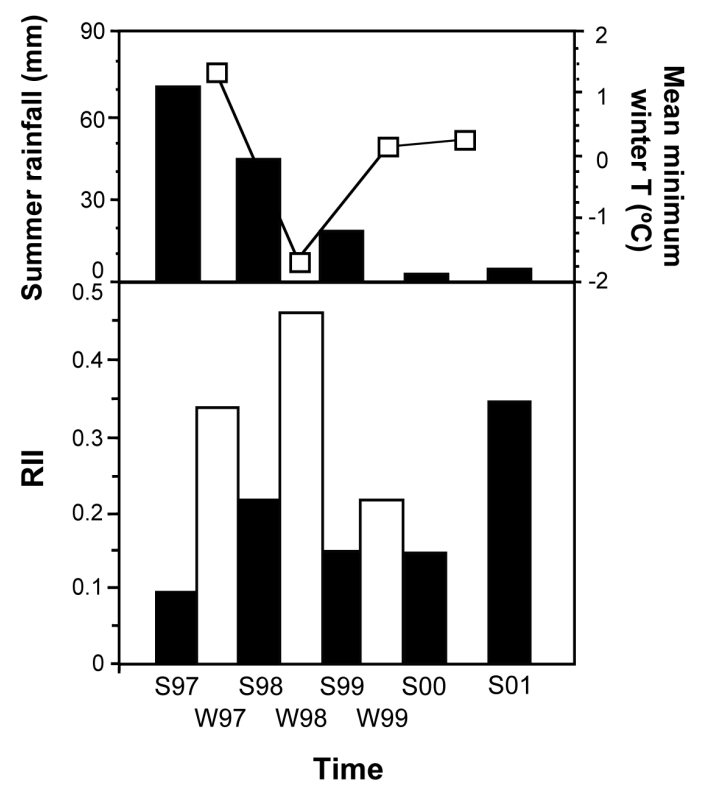

Fig. 2. Temporal variability of the facilitative effect of shrubs on sapling survival, and its relationship with climatic characteristics (climatic data obtained at a meteorological station located in La Cortijuela Botanical Garden, $1 \mathrm{~km}$ from the study site). In the upper graph, black bars represent summer rainfall (sum of mm fallen in June, July and August) and open squares represent the mean minimum temperature during winter months (December, January and February). In the lower graph, bars represent the magnitude of facilitation quantified by the RII (Relative Interaction Index). Due to the lack of survival data for winter 2000, RII could not be calculated for that period. Therefore, RII for summer 2001 was calculated with survival data after one entire year. 


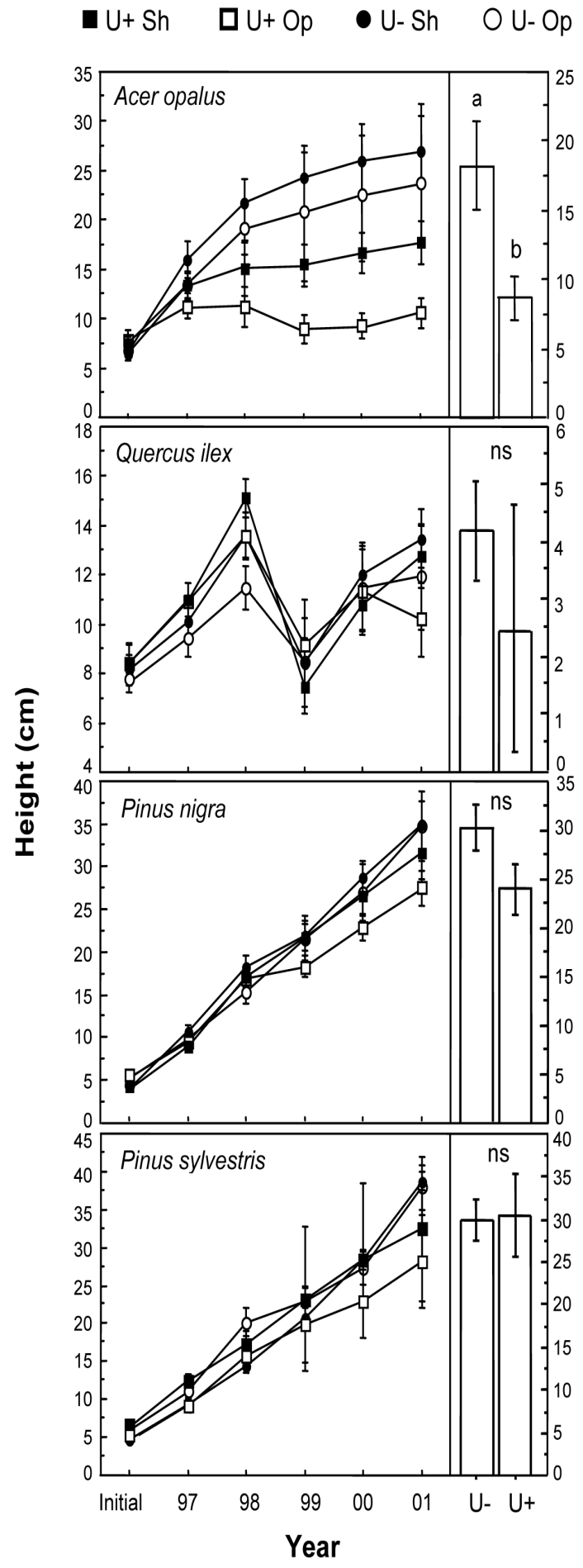

Fig. 3. Change of sapling height over the 5 study years in the four experimental treatments. Bars represent the accumulated growth in height $(\mathrm{cm})$ after 5 years. U+ = control plots; $\mathrm{U}_{-}=$ ungulate-excluded plots; $\mathrm{Sh}=$ shrub microhabitat; $\mathrm{Op}=$ open microhabitat. Values are mean $\pm 1 \mathrm{SE}$
Table 3. MANOVAs analysing the effect of ungulate exclusion and microhabitat on sapling height growth of each of the 4 species throughout the 5 years of the study. Block was not considered in the analysis because not all combinations of the three factors had live saplings at the end of the experiment.

\begin{tabular}{|c|c|c|c|c|c|}
\hline Source of variation & $\begin{array}{c}\mathrm{df} \\
\text { Num }\end{array}$ & $\begin{array}{c}\mathrm{df} \\
\text { Den }\end{array}$ & $\lambda$ & $F$ & $p$ \\
\hline \multicolumn{6}{|l|}{ Acer opalus } \\
\hline Ungulate exclusion (U) & 1 & 43 & 0.43 & 5.96 & 0.014 \\
\hline Microhabitat (M) & 1 & 43 & 0.99 & 0.44 & 0.508 \\
\hline $\mathrm{U} \times \mathrm{M}$ & 1 & 43 & 0.49 & 4.89 & 0.032 \\
\hline Year $(\mathrm{Y})$ & 4 & 40 & 0.29 & 23.69 & $<0.0001$ \\
\hline $\mathrm{Y} \times \mathrm{U}$ & 4 & 40 & 0.87 & 1.47 & 0.227 \\
\hline $\mathrm{Y} \times \mathrm{M}$ & 4 & 40 & 0.91 & 1.02 & 0.407 \\
\hline $\mathrm{Y} \times \mathrm{U} \times \mathrm{M}$ & 4 & 40 & 0.98 & 0.24 & 0.913 \\
\hline \multicolumn{6}{|l|}{ Quercus ilex } \\
\hline $\mathrm{U}$ & 1 & 51 & 0.98 & 0.58 & 0.449 \\
\hline M & 1 & 51 & 0.99 & 0.61 & 0.437 \\
\hline $\mathrm{U} \times \mathrm{M}$ & 1 & 51 & 0.98 & 0.77 & 0.385 \\
\hline $\mathrm{Y}$ & 4 & 48 & 0.12 & 88.81 & $<0.0001$ \\
\hline $\mathrm{Y} \times \mathrm{U}$ & 4 & 48 & 0.91 & 1.19 & 0.326 \\
\hline $\mathrm{Y} \times \mathrm{M}$ & 4 & 48 & 0.76 & 3.73 & 0.010 \\
\hline $\mathrm{Y} \times \mathrm{U} \times \mathrm{M}$ & 4 & 48 & 0.83 & 2.45 & 0.059 \\
\hline \multicolumn{6}{|l|}{ Pinus nigra } \\
\hline $\mathrm{U}$ & 1 & 57 & 0.98 & 1.12 & 0.293 \\
\hline M & 1 & 57 & 0.98 & 0.84 & 0.361 \\
\hline $\mathrm{U} \times \mathrm{M}$ & 1 & 57 & 0.99 & 0.00 & 0.951 \\
\hline $\mathrm{Y}$ & 4 & 54 & 0.10 & 114.07 & $<0.0001$ \\
\hline $\mathrm{Y} \times \mathrm{U}$ & 4 & 54 & 0.90 & 1.46 & 0.226 \\
\hline $\mathrm{Y} \times \mathrm{M}$ & 4 & 54 & 0.88 & 1.89 & 0.126 \\
\hline $\mathrm{Y} \times \mathrm{U} \times \mathrm{M}$ & 4 & 54 & 0.87 & 1.90 & 0.124 \\
\hline \multicolumn{6}{|l|}{ Pinus sylvestris } \\
\hline $\mathrm{U}$ & 1 & 15 & 0.98 & 0.32 & 0.581 \\
\hline M & 1 & 15 & 0.95 & 0.74 & 0.402 \\
\hline $\mathrm{U} \times \mathrm{M}$ & 1 & 15 & 0.98 & 0.22 & 0.646 \\
\hline $\mathrm{Y}$ & 4 & 12 & 0.06 & 49.19 & $<0.0001$ \\
\hline $\mathrm{Y} \times \mathrm{U}$ & 4 & 12 & 0.46 & 3.47 & 0.041 \\
\hline $\mathrm{Y} \times \mathrm{M}$ & 4 & 12 & 0.88 & 0.42 & 0.792 \\
\hline $\mathrm{Y} \times \mathrm{U} \times \mathrm{M}$ & 4 & 12 & 0.64 & 1.68 & 0.217 \\
\hline
\end{tabular}

\section{Herbivory damage}

The risk of herbivory differed significantly among blocks in all years, although the pattern changed depending on the year (Table 4). The risk of herbivory varied between microhabitats only in the last three years of study, although significance disappeared after Bonferroni correction (Table 4). As for the block factor, betweenmicrohabitat variation did not present a congruent inter-annual pattern; the risk of herbivory was higher in the open in 1999 and 2000 and higher under shrubs in 2001. The risk of herbivory varied significantly between species throughout the five years of the study (Table 4). A. opalus was the most damaged species $(50.3 \pm 8.7 \%$ annual mean, Fig. 4), the herbivory risk reaching values of $80 \%$ in some years. $Q$. ilex was the least damaged (6.5 \pm 2.4\%), whereas P. nigra and P. sylvestris had intermediate 


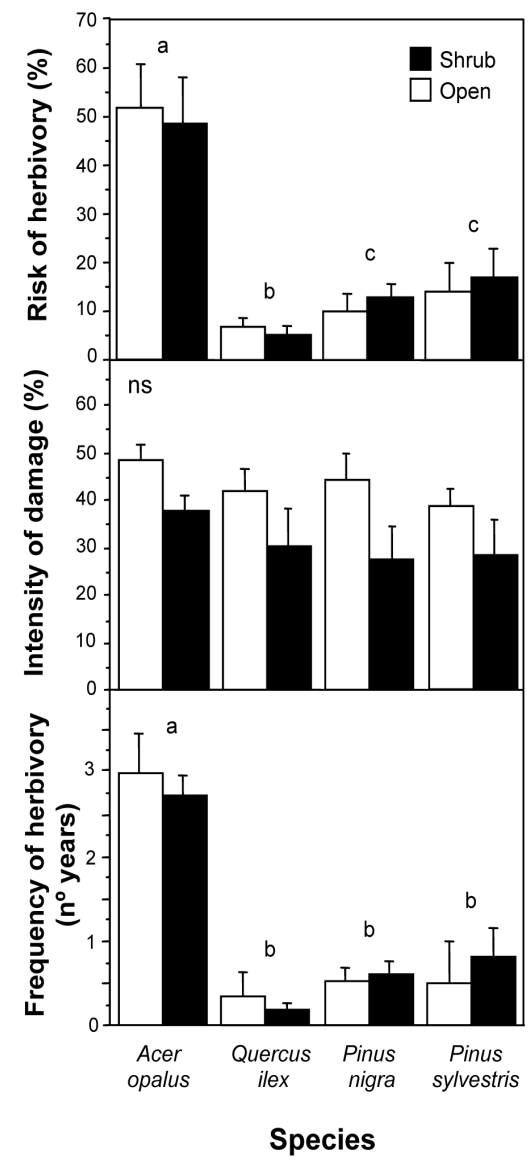

Fig. 4. Risk of herbivory, frequency of herbivory, and damage intensity of saplings alive at the end of the experiment (mean \pm 1 SE for the five years of study). Different letters show significant differences among species after Bonferroni correction. There were no differences among microhabitats in any case. and similar values $(12.8 \pm 3.4 \%$ and $13.4 \pm 5.9 \%$, respectively; Fig. 4). The intensity of damage differed between blocks only in the first year (Table 4). It did not differ between microhabitats or among species in any year of study (Table 4), although values were always lower under shrubs than in open interspaces (Fig. 4). The frequency of herbivory did not differ between microhabitats (L-R $\left.\chi^{2}=0.01, \mathrm{df}=1, p=0.90\right)$ but it did between species (L-R $\left.\chi^{2}=41.96, \mathrm{df}=3, p<0.0001\right)$. Thus, while it was $<1$ for $Q$. ilex and both Pinus species, it almost reached three for A. opalus (Fig. 4). Accordingly, all A. opalus saplings alive outside the exclosures at the end of the experiment were damaged in at least one year.

\section{Discussion}

\section{Facilitation of sapling survival: The role of microhabitat amelioration}

Shrubs had a similar positive effect on sapling survival both inside and outside exclosures. Therefore, neither the sign nor the strength of the shrub-sapling interaction was determined by the presence of ungulates. Instead, microhabitat amelioration was the main facilitation mechanism. Extreme abiotic conditions, primarily summer drought and winter frosts, were the main mortality causes ( $98.7 \%$ of the total mortality). In this scenario, shrub canopies generated a distinctive micro-environment that proved crucial for saplings to survive both critical seasons. Thus, in mid-summer shrubs attenuated radiation by $70 \%$, providing moderate shade able to increase survival and reduce photo-inhibition of

Table 4. Summary of the models that analyse the differences between blocks, microhabitats, and species in the risk of herbivory and intensity of damage of experimental saplings in each of the 5 years of study. Models are Generalized Logit Models for risk of herbivory (L-R $\chi^{2}$ values) and Generalized Linear Models ( $\mathrm{F}$ values) for intensity of damage.

\begin{tabular}{|c|c|c|c|c|c|c|c|c|c|c|}
\hline \multirow{2}{*}{$\begin{array}{l}\text { Source of variation } \\
\text { Risk of herbivory }\end{array}$} & \multirow[t]{2}{*}{ df } & \multicolumn{2}{|c|}{1997} & \multicolumn{2}{|c|}{1998} & \multicolumn{2}{|c|}{$\begin{array}{l}\text { Year } \\
1999\end{array}$} & \multicolumn{2}{|c|}{2000} & 2001 \\
\hline & & & & & & & & & & \\
\hline Block (B) & 4 & 41.25 & $* * *$ & 11.73 & $*$ & 22.12 & $* * *$ & 14.51 & $* *$ & $14.28 * *$ \\
\hline Microhabitat (M) & 2 & 3.27 & & 0.01 & & 9.18 & $*$ & 8.25 & $*$ & $7.30 *$ \\
\hline Species $(\mathrm{S})$ & 6 & 85.27 & $* * * *$ & 98.39 & ***** & 56.52 & $* * * *$ & 29.82 & $* * * *$ & $40.07 * * * *$ \\
\hline $\mathrm{B} \times \mathrm{M}$ & 8 & 0.07 & & 1.09 & & 0.98 & & 1.24 & & 1.33 \\
\hline $\mathrm{B} \times \mathrm{S}$ & 12 & 28.92 & ** & 8.62 & & 10.15 & & 11.53 & & 15.62 \\
\hline $\mathrm{M} \times \mathrm{S}$ & 6 & 18.25 & $* *$ & 6.95 & & 14.86 & $*$ & 8.29 & & 10.30 \\
\hline \multicolumn{11}{|l|}{ Intensity of damage } \\
\hline B & 2 & 5.46 & $* *$ & 0.27 & & 0.87 & & 0.12 & & $3.93 *$ \\
\hline M & 1 & 1.91 & & 0.22 & & 0.03 & & 0.16 & & 0.67 \\
\hline $\mathrm{S}$ & 3 & 1.27 & & 1.59 & & 0.19 & & 0.22 & & 0.14 \\
\hline $\mathrm{B} \times \mathrm{M}$ & 2 & 0.65 & & 0.45 & & 2.93 & & 0.98 & & 0.78 \\
\hline $\mathrm{B} \times \mathrm{S}$ & 6 & 9.09 & & 7.89 & & 5.47 & & 9.67 & & 8.80 \\
\hline $\mathrm{M} \times \mathrm{S}$ & 3 & 0.45 & & 1.28 & & 0.34 & & 1.16 & & 0.21 \\
\hline
\end{tabular}

Note: Asterisks denote the following significant levels: $* * * * p<0.0001, * * * p<0.001, * * p<0.01, * p<0.05$. Significant values (after Bonferroni correction) are in bold. 
woody saplings without significantly limiting carbon gain (Valladares et al. 2005; Gómez-Aparicio et al. 2006). As a result of reduced irradiance, the mean air temperature diminished by almost $10^{\circ} \mathrm{C}$, in turn reducing the risk of leaf overheating, an important stress factor in environments where drought limits cooling by transpiration (Larcher 1995). Moreover, VPD under shrubs was about half that in open interspaces. These environmental changes can improve the water status of saplings even in the absence of between-microhabitat differences in soil water content, as happened in this study (Holmgren et al. 1997; Domingo et al. 1999). Although microclimatic differences between microhabitats were not evaluated in winter, shrubs presumably also ameliorate negative temperatures, reducing the risk of frost damage to tissues (Kikvidze \& Nakhutsrishvili 1998; Núñez et al. 1999). Moreover, litter accumulation under shrubs might reduce heaving of the soil surface during freeze-thaw cycles, diminishing mortality due to uprooting and/or fracture (Gill \& Marks 1991; Gobbi \& Schlichter 1998).

Facilitation of sapling survival occurred throughout the five study years, as indicated by the positive values of RII (Fig. 2). This finding suggests that the nurse effect of shrubs, reported mainly for the first year of life of tree seedlings (Maestre et al. 2003; Gómez-Aparicio et al. 2004), is consistent throughout the sapling stage (see also Castro et al. 2004, 2006). At the intra-annual scale, facilitation by shrubs due to microclimatic amelioration in mediterranean environments has been reported mainly during the summer season (Callaway 1992; Rousset \& Lepart 1999; Castro et al. 2004a). However, our study shows that, at high altitudes in the Mediterranean mountains, where plants are exposed to a double abiotic stress comprised of drought and frosts (Terradas 2001), protection by shrubs in winter can be even more important than in summer (Fig. 2). Specifically in winter 1998, which was particularly cold, survival under shrubs was four times higher than in open spaces. Moreover, the lowest beneficial effect of shrubs occurred during the first summer, which was unusually wet (see Gómez-Aparicio et al. 2004). In fact, summer 1997 was the second wettest summer of the twentieth-century in the study area (Gómez-Aparicio et al. 2005c). Therefore, our results support the general hypothesis that predicts facilitation to increase with environmental severity (Bertness \& Callaway 1994).

Despite sapling survival for the four species being higher under shrubs than in open areas, amongmicrohabitat differences were significant only for $Q$. ilex and especially for A. opalus. In fact, A. opalus not only had the greatest increase in survival under shrubs in comparison to bare soil, but this response was highly consistent in space; it was the only species for which there were no significant qualitative or quantitative differences among experimental blocks. The weak response shown by $P$. nigra to the presence of shrubs agrees with the light-demanding characteristic associated with the genus Pinus (Ceballos \& Ruíz de la Torre 1971; Keeley \& Zedler 1998). Thus, P. nigra saplings have been shown to be more tolerant to the strong irradiance characteristic of the open microhabitat than $Q$. ilex and A. opalus saplings (Gómez-Aparicio et al. 2006). For these three Mediterranean species, the response to the presence of shrubs ranked inversely to their performance in the sun, which was highest for $P$. nigra (38.1\% survival), followed by $Q$.ilex $(29.9 \%)$ and A. opalus (18.1\%). In contrast, P. sylvestris had both the lowest survival percentage in the sun and the lowest response to shrubs. This finding is probably related to the fact that $P$. sylvestris is a boreal-alpine species that reaches its southernmost distribution limit in Sierra Nevada (Boratynski 1991). Under such extreme abiotic conditions, not even the presence of spiny shrubs effectively altered the micro-environment to increase $P$. sylvestris saplings survival (but see Castro et. al. 2004b). In general, our results show that the microclimatic effect of shrubs is more beneficial for stress-intolerant (i.e. A. opalus) than for stress-tolerant species (i.e. $P$. nigra) (Gómez-Aparicio et al. 2005b; Rey-Benayas et al. 2005), but that facilitation can wane when environmental conditions are too stressful for a species (i.e. $P$. sylvestris) (Michalet et al. 2006).

\section{Facilitation of sapling growth: the role of herbivore protection}

The exclosure of ungulates for five years did not boost sapling survival. However, it significantly affected sapling growth, but only for A. opalus. This species-specific effect of the exclosures is connected to the fact that $A$. opalus saplings had more than a threefold higher risk and frequency of herbivory than any other tree species (Fig. 4). This finding agrees with chemical data that show A. opalus to be the most palatable species of the four studied here, due to a higher content of foliar nitrogen and a lower content of tannins and phenolic compounds (Baraza 2004). Thus, every A. opalus sapling outside the exclosures was damaged at least once during the study period, and saplings accumulated more than twice the height growth inside the exclosures $(18.2 \pm 2.6 \mathrm{~cm})$ than outside the exclosures $(8.5 \pm 1.5 \mathrm{~cm})$ (Fig. 3). For small saplings of less palatable species such as $Q$. ilex or Pinus spp., even a period of five years of herbivory may be insufficient to appreciate the negative effects of ungulates, which become more relevant when saplings are larger (Zamora et al. 2001; Baraza 2004). 
The fact that after five years all A. opalus saplings outside the exclosures were damaged, whether in the shrub or open microhabitat, suggests that shrubs did not act efficiently as refuges from ungulates. This result is presumably influenced by the fact that the spiny shrubs used as nurse plants have several characteristics limiting this potential protective role, such as a small to medium size, a growth architecture that leaves open spaces beneath them and an isolated spatial distribution, each individual shrub being surrounded by open space with stunted shrubs. For these reasons, saplings planted beneath shrubs were relatively accessible to ungulates. There is now growing evidence indicating that the protective effect of nurse shrubs is highly dependent on their physical and chemical traits (Bruno et al. 2003; Garcia et al. 2005; Baraza et al. 2006). Therefore, nurse shrubs with different structural characteristics (e.g. shrubs with canopy reaching the soil surface, larger shrubs and/or clumped shrub patches surrounding the saplings, unpalatable shrub species) would presumably have provided a better refuge from ungulates (Gómez et al. 2001).

Although herbivory damage to $A$. opalus did not differ between microhabitats, A. opalus saplings outside the exclosures, but not inside, were significantly higher under shrubs than in open interspaces. This result suggests that shrubs had a positive effect on height growth that was not directly mediated by microhabitat amelioration, but rather involved herbivores. Since herbivory damage did not vary between microhabitats, shrubs could have increased the tolerance of $A$. opalus saplings to herbivory by decreasing drought stress, in accordance with the continuum of plant response model (Maschinski \& Whitman 1989) that predicts a higher ability of plants to compensate for herbivory in low stress environments (see also Rand 2004). In fact, shrubs are the only microhabitat where Acer saplings have a high probability of growing to maturity in the study area (Zamora et al. 2004).

\section{Concluding remarks: Relative importance of micro- climate modification vs. protection as a facilitation mechanism}

Current theoretical models predict that facilitation increases with environmental stress (Bertness \& Callaway 1994), although its importance can decrease at the extreme end of an environmental severity gradient (Michalet et al. 2006). Therefore, with the exception of extremely severe environments, we can expect the importance of the different mechanisms of facilitation to depend on the relative magnitude of the different stresses acting in a system. Furthermore, a proper evaluation of the final balance among the different mechanisms requires an adequate timing template. In stressful environments such as Mediterranean mountains, tree saplings grow very slowly (Zamora et al. 2001), necessitating long-term studies to fully understand the importance for plant performance of different abiotic and biotic stress sources (e.g. summer drought, winter frosts, herbivory). Our relatively long-term study clearly indicates that, in our study area, abiotic stress was more intense than biotic stress (i.e. herbivory) due to the combination of summer drought and winter frosts. Consequently, microclimate amelioration constituted by far the main benefit for saplings established under shrubs. In summary, the relative importance of the modification of the microclimate vs. protection against herbivory as facilitation mechanisms can be expected to vary strongly among systems, depending on the climatic characteristics of the year, the herbivore pressure and the characteristics of the plant species interacting (see e.g. Turner et al. 1969; Steenberg \& Lowe 1969; Valiente-Banuet \& Ezcurra 1991; Callaway et al. 1996; Baraza et al. 2006).

Acknowledgements. We thank the Consejería de Medio Ambiente, Junta de Andalucía, and the direction of the National Park, for permission to work in Sierra Nevada. We are especially grateful to Empresa de Transformación Agraria S.A. (TRAGSA) for carrying out the experimental plantations. Jose M. Gómez, Sergio de Haro, Elena Baraza and Daniel García kindly helped with the field work. David Nesbitt looked over the English version of the manuscript. This study was supported by a PFPU-MECD grant to L.G.A., the Andalusian government grant (PAI) rnm-220, and projects FEDER 1FD97-0743-CO302 and HETEROMED REN2002-04041-CO2-01/GLO from the Spanish Ministry of Science and Technology (MCYT). 


\section{References}

Anon. 2002. SAS/STAT user's guide. Version 8.2. SAS Institute, Cary, North Carolina, US.

Allison, P.D. 1995. Survival analysis using the SAS system: a practical guide. SAS Institute, Cary, North Carolina, US.

Alverson, W.S. \& Waller, D.M. 1997. Deer population and the widespread failure of hemlock regeneration in northern forests. In: McShea, W.J., Underwood, H.B. \& Rappole, J.H. (eds.) The science of over-abundance: deer ecology and population management, pp. 280-297. Smithsonian Institution Press, Washington, DC, US.

Armas, C., Ordiales, R. \& Pugnaire, F.I. 2004. Measuring plant interactions: a new comparative index. Ecology 85: 2682-2686.

Bakker, E.S., Olff, H., Vandenberghe, C., de Maeyer, K., Smith, R., Gleichman, J.M. \& Vera, F.W.M. 2004. Ecological anachronisms in the recruitment of temperate light-demanding tree species in wooded pastures. Journal of Applied Ecology 41: 571-582.

Baraza, E. 2004. Efecto de los pequeños ungulados en la regeneración del bosque mediterráneo de montaña: desde la química hasta el paisaje. Ph.D. Thesis, University of Granada, ES.

Baraza, E., Zamora, R. \& Hódar, J.A. 2006. Conditional outcomes in plant-herbivore interactions: neighbours matters. Oikos 113: 148-156.

Bertness, M.D. \& Callaway, R.M. 1994. Positive interactions in communities. Trends in Ecology and Evolution 9: 191-193.

Boratynski,A. 1991. Range of natural distribution. In: Giertych, M. \& Mátyás, C. (eds.) Genetics of P. sylvestris, pp. 19-30. Akadémiai Kiadó, Budapest, HU.

Brown, B.J. \& Ewel, J.J. 1987. Herbivory in complex tropical successional ecosystems. Ecology 68: 108-116.

Brown, J.H., Whitham, T.G., Ernest, S.K.M. \& Gehring, C.A. 2001. Complex species interactions and the dynamics of ecological systems: long-term experiments. Science 293: 643-650.

Bruno, J.F., Stachowicz, J.J. \& Bertness, M.D. 2003. Inclusion of facilitation into ecological theory. Trends in Ecology and Evolution 18: 119-125.

Cabin, R.J. \& Mitchell, R.J. 2000. To Bonferroni or not to Bonferroni: when and how are the questions. Bulletin of the Ecological Society of America 81: 246-248.

Callaway, R.M. 1992. Effect of shrubs on recruitment of Quercus douglasii and Quercus lobata in California. Ecology 73: 2118-2128.

Callaway, R.M. \& Pugnaire, F.I. 1999. Facilitation in plant communities. In: Pugnaire, F.I. \& Valladares, F. (eds.) Handbook of functional plant ecology, pp. 623-648. Marcel Dekker Inc., NY, US.

Callaway, R.M., Delucia, E.H., Moore, D., Nowak, R. \& Schlesinger, W.H. 1996. Competition and facilitation: contrasting effects of Artemisia tridentata on desert vs. mountain pines. Ecology 77: 2130-2141.

Callaway, R.M., Brooker, R.W., Choler, P., Kikvidze,Z., Lortie, C.J., Michalet, R., Paolini, L., Pugnaire, F.I., Newingham,
B., Aschehoug, E.T., Armas, C., Kikodze, D. \& Cook, B.J. 2002. Positive interactions among alpine plants increase with stress. Nature 417:844-848.

Castro, J., Zamora, R., Hódar, J.A. \& Gómez, J.M. 2002. Use of shrubs as nurse plants: a new technique for reforestation in Mediterranean mountains. Restoration Ecology 10: 297-305.

Castro, J., Zamora, R., Hódar, J.A. \& Gómez, J.M. 2004a. Seedling establishment of a boreal tree species (Pinus sylvestris) at its southernmost distribution limit: consequences of being in a marginal Mediterranean area. Journal of Ecology 92: 266-277.

Castro, J., Zamora, R., Hódar, J.A., Gómez, J.M. \& GómezAparicio, L. 2004b. Benefits of using shrubs as nurse plants for reforestation in Mediterranean mountains: a 4-year study. Restoration Ecology 12: 352-358.

Castro, J., Zamora, R., Hódar, J.A. \& Gómez, J.M. 2005. Alleviation of summer drought boost establishment success of Pinus sylvestris in a Mediterranean mountain: an experimental approach. Plant Ecology 181: 191-202.

Castro, J., Zamora, R. \& Hódar, J.A. 2006. Restoring the forests of Quercus pyrenaica Willd. using pioneer shrubs as nurse plants. Applied Vegetation Science 9: 137-142.

Castroviejo, S., Laínz, M., López-González, G., Montserrat, P., Muñoz-Garmendia, F., Paiva, J. \& Villar, I. (eds) 19862001. Flora Iberica. CSIC, Madrid, ES.

Ceballos, L. \& Ruiz de la Torre, J. 1971. Árboles y arbustos de la España peninsular. Instituto Forestal de Investigaciones y Experiencias. Escuela Técnica Superior de Ingenieros de Montes, Madrid, ES.

Crawley, M.J. 1997. Plant-herbivore dynamics. In: Crawley, M.J.(ed.) Plant Ecology, 2nd. ed., pp. 401-474. Blackwell, Oxford, UK.

Cuartas, P. \& García-González, R. 1992. Quercus ilex browse utilization by Caprini in Sierra de Cazorla and Segura (Spain). Vegetatio 99-100: 317-330.

Domingo, F., Villagarcía, L., Brenner, A.J. \& Puigdefábregas, J. 1999. Evapotranspiration model for semi-arid shrub-lands tested against data from SE Spain. Agricultural and Forest Meteorology 95: 67-84.

García, D. 2001. Effects of seed dispersal on Juniperus communis recruitment on a Mediterranean mountain. Journal of Vegetation Science 12: 839-848.

García, D. \& Obeso, J.R. 2003. Facilitation by herbivoremediated nurse plants in a threatened tree, Taxus baccata: local effects and landscape level consistency. Ecography 26: 739-750.

García, D., Zamora, R., Hódar, J.A., Gómez, J.M. \& Castro, J. 2000. Yew (Taxus baccata L.) regeneration is facilitated by fleshy-fruited shrubs in Mediterranean environments. Biological Conservation 95: 31-38.

Gill, D.S. \& Marks, P.L. 1991. Tree and shrub seedling colonization in old fields in central New York. Ecological Monographs 61: 183-205.

Gobbi, M. \& Schlichter, T. 1998. Survival of Austrocedrus chilensis seedlings in relation to microsite conditions and forest thinning. Forest Ecology and Management 111: 137-146.

Gómez, J.M., Hódar, J.A., Zamora, R., Castro, J. \& García, D. 
2001. Ungulate damage on Scots pines in Mediterranean environments: effects of association with shrubs. Canadian Journal of Botany 79: 739-746.

Gómez-Aparicio, L., Zamora, R., Gómez, J.M., Hódar, J.A., Castro, J. \& Baraza, E. 2004. Applying plant facilitation to forest restoration in Mediterranean ecosystems: a metaanalysis of the use of shrubs as nurse plants. Ecological Applications 14: 1128-1138.

Gómez-Aparicio, L., Gómez, J.M., Zamora, R. \& Boettinger, J.L. 2005a. Canopy vs. soil effects of shrubs facilitating tree seedlings in Mediterranean montane ecosystems. Journal of Vegetation Science 16: 191-198.

Gómez-Aparicio, L., Valladares, F., Zamora, R. \& Quero, J.L. 2005b. Response of tree seedlings to the abiotic heterogeneity generated by nurse shrubs: an experimental approach at different scales. Ecography 28: 757-768.

Gómez-Aparicio, L., Gómez, J.M. \& Zamora, R. 2005c. Microhabitats shift rank in suitability for seedling establishment depending on habitat type and climate. Journal of Ecology 93: 1194-1202.

Gómez-Aparicio, L., Valladares, F. \& Zamora, R. 2006. Differential light responses of Mediterranean tree saplings: linking ecophysiology with regeneration niche in four co-occurring species. Tree Physiology 26: 947-958.

Griffin, J.R. 1971. Quercus regeneration in the Upper Carmel Valley, California. Ecology 52: 862-868.

Herrera, C.M., Jordano, P., López-Soria, L. \& Amat, J.A. 1994. Recruitment of a mast-fruiting, bird-dispersed tree: bridging frugivore activity and seedling establishment. Ecological Monographs 64: 315-344.

Hjältén, J. \& Price, P.W. 1997. Can plants gain protection from herbivory by association with unpalatable neighbours?: a field experiment in a willow-sawfly system. Oikos 78: 317-322.

Holmgren, M., Scheffer, M. \& Huston, M.A. 1997. The interplay of facilitation and competition in plant communities. Ecology 78: 1966-1975.

Huntly, N. 1991. Herbivores and the dynamics of communities and ecosystems. Annual Review of Ecology, Evolution \& Systematics 22: 477-503.

Ibañez, I. \& Schupp, E.W. 2001. Positive and negative interactions between environmental conditions affecting Cercocarpus ledifolius seedling survival. Oecologia 129: 543-550.

Keeley, J.E. \& Zedler, P.H. 1998. Evolution of life histories in Pinus. In: Richardson, D.M. (ed.) Ecology and biogeography of Pinus, pp. 219-249. Cambridge University Press, Cambridge, UK.

Kikvidze, Z. \& Nakhutsrishvili, G. 1998. Facilitation in subnival vegetation patches. Journal of Vegetation Science 9: 261-264.

Larcher, W. 1995. Physiological plant ecology. Ecophysiology and stress physiology of functional groups. Springer-Verlag, Berlin, DE.

Maestre, F.T., Bautista, S. \& Cortina, J. 2003. Positive, negative and net effects in grass-shrub interactions in Mediterranean semiarid grasslands. Ecology 84: 3186-3197.

Maschinski, J. \& Whithman, T.G. 1989. The continuum of plant response to herbivory: the influence of plant association, nutrient availability and timing. The American Naturalist 134: 1-19.

Meiners, S.J. \& Martinkovic, M.J. 2002. Survival of and herbivore damage to a cohort of Quercus rubra planted across a forest-old-field edge. American Midland Naturalist 147: 247-256.

Mesón, M. \& Montoya, M. 1993. Selvicultura Mediterránea. Mundi Prensa, Madrid, ES.

Michalet, R., Brooker, R.W., Cavieres, L.A., Kikvidze, Z., Lortie, C.J., Pugnaire, F.I., Valiente-Banuet,A. \& Callaway, R.M. 2006. Do biotic interactions shape both sides of the humped-back model of species richness in plant communities? Ecology Letters 9: 767-773.

Molero-Mesa, J., Pérez-Raya, F. \& Valle, F. 1992. Parque Natural de Sierra Nevada: paisaje, fauna, flora, itinerarios. Rueda, Madrid, ES.

Mulder, C.P.H., Uliassi, D.D. \& Doak, D.F. 2001. Physical stress and diversity-productivity relationships: the role of positive relations. Proceedings of the National Academy of Sciences of the United States of America 98: 6704-6708.

Nuñez, C.I., Aizen, M.A. \& Ezcurra, C. 1999. Species associations and nurse plant effects in patches of high-Andean vegetation. Journal of Vegetation Science 10: 357-364.

Pickett, S.T.A., Collins, S.L. \& Armesto, J.J. 1987. Models, mechanisms and pathways of succession. Botanical Review 53: 335-371.

Rand, T. 2004. Competition, facilitation and compensation for insect herbivory in an annual salt marsh forb. Ecology 85: 2046-2052.

Rebollo, S., Milchunas, D.G., Noy-Meir, I. \& Chapman, P.L. 2002. The role of spiny plant refuge in structuring grazed shortgrass steppe plant communities. Oikos 98: 53-64.

Rey, P.J. \& Alcántara, J.M. 2000. Recruitment dynamics of a fleshy-fruited plant (Olea europaea): connecting patterns of seed dispersal to seedling establishment. Journal of Ecology 88: 622-633.

Rey-Benayas, J.M., Navarro, J., Espigares, T., Nicolau, J.M. \& Zavala, M.A. 2005. Effects of artificial shading and weed mowing in reforestation of Mediterranean abandoned cropland with contrasting Quercus species. Forest Ecology and Management 212: 302-314.

Roughgarden, J. \& Diamond, J. 1986. The role of species interactions in community ecology. In: Diamond, J. \& Case, T. J. (eds.) Community Ecology, pp. 333-343. Harper \& Row Publishers Inc., NY, US.

Rousset, O. \& Lepart, J. 1999. Shrub facilitation of Quercus humilis regeneration in succession on calcareous grasslands. Journal of Vegetation Science 10: 493-502.

Steenberg, W.F. \& Lowe, C.H. 1969. Critical factors during the first year of life of the saguaro (Cereus giganteus) at Saguaro National Monument. Ecology 50: 825-834.

Terradas, J. 2001. Ecología de la vegetación. De la ecofisiología de las plantas a la dinámica de comunidades y paisajes. Omega. Barcelona, ES.

Tewksbury, J.J. \& Lloyd, J. D. 2001. Positive interactions under nurse plants: spatial scale, stress gradients and benefactor size. Oecologia 127: 425-434.

Traveset, A., Gulias, J., Riera, N. \& Mus, M. 2003. Transition probabilities from pollination to establishment in a rare 
dioecious shrub species (Rhamnus ludovici-salvatoris) in two habitats. Journal of Ecology 91: 427-437.

Turner, R.M., Alcorn, S.M. \& Olin, G. 1969. Mortality of transplanted saguaro seedlings. Ecology 50: 835-844.

Valiente-Banuet, A. \& Ezcurra, E. 1991. Shade as a cause of the association between the cactus Neobuxbaumia tetetzo and the nurse plant Mimosa luisana in the Tehuacan Valley, Mexico. Journal of Ecology 79: 961-971.

Valladares, F., Dobarro, I., Sánchez-Gómez, D. \& Pearcy, R.W. 2005. Photoinhibition and drought in Mediterranean woody saplings: scaling effects and interactions in sun and shade phenotypes. Journal of Experimental Botany 56: 483-494.

Von Ende, C.N. 2001. Repeated-measures analysis: growth and other time-dependent measures. In: Scheiner, S.M. \& Gurevitch, J. (eds.) Design and analysis of ecological experiments, 2nd. ed., pp. 134-157. Oxford University
Press, Oxford, UK.

Zamora, R., Gómez, J.M. \& Hódar, J.A. 2000. Las interacciones entre plantas y animales en el Mediterráneo: importancia del contexto ecológico y el nivel de organización. In: Ecosistemas Mediterráneos: análisis funcional, pp. 237268. Colección Textos Universitarios No 32. AEET-CSIC, Madrid, ES.

Zamora, R., Gómez, J.M., Hódar, J.A., Castro, J. \& García, D. 2001. Effects of browsing by ungulates on sapling growth of Scots pine in a Mediterranean environment: consequences for forest regeneration. Forest Ecology and Management 144: 33-42.

Zamora, R., García-Fayos, P. \& Gómez-Aparicio, L. 2004. Las interacciones planta-planta y planta-animal en el contexto de la sucesión ecológica. In: Valladares, F. (ed.) Ecología del bosque Mediterráneo en un mundo cambiante, pp. 371393. Editorial Parques Nacionales, Madrid, ES.

Received 11 September 2006; Accepted 22 June 2007; Co-ordinating Editor: P.M. Dixon. 